\title{
PENGEMBANGAN MEDIA PEMBELAJARAN BERBASIS VIRTUAL REALITY PADA MATA KULIAH ANATOMI DAN FISIOLOGI MANUSIA PADA MAHASISWA SEMESTER VI PENDIDIKAN BIOLOGI
}

\author{
${ }^{1}$ Ahmad Khuzeir Tarmizi, ${ }^{2}$ Haning Hasbiyati, ${ }^{3}$ Miftahul Hakim \\ ${ }^{123}$ Pendidikan Biologi, Universitas Islam Jember \\ 1khuzer16@gmail.com,2haninghasbiyati@gmail.com, ${ }^{3}$ cak.kiem81@gmail.com
}

\begin{abstract}
ABSTRAK
Pengembangan media pembelajaran berbasis Virtual reality bertujuan untuk mengetahui kelayakan media ini dalam pembelajaran. Media ini divalidasi oleh dua ahli yaitu ahli materi dan ahli media. Saat validasi ahli materi media ini mendapat persentase penilaian $79,8 \%$ serta dalam pengujiannya dalam validasi ahli media mendapatkan persentase $96,8 \%$, yang berarti uji sangat valid. Uji coba sampel sebanyak 9 orang, mendapat skor persentase $74,6 \%$ (sangat layak) sedangkan, saat uji coba penerapan terdapat sekitar 19 orang mendapatkan persentase skor 79,2 (sangat layak). Dari uji coba tersebut dapat disimpulkan bahwasanya media pembelajaran virtual reality sangat layak dan dapat diimplementasikan ke dalam proses pembelajaran nyata.
\end{abstract}

Kata Kunci: Anatomi dan Fisiologi Manusia, Pengembangan Virtual Reality, Media Pembelajaran

\begin{abstract}
The development of learning media based on virtual reality aims to determine the feasibility of this media in learning. This media is validated by two experts, namely material experts and media experts. During the validation of the media material expert, he received an assessment percentage of $79.8 \%$ and in his testing the media expert validation received a percentage of $96.8 \%$, which means that the test is very valid. The sample trial was 9 people, got a percentage score of $74.6 \%$ (very feasible), while during the implementation trial there were about 19 people who got a percentage score of 79.2 (very feasible). From these trials it can be concluded that virtual reality learning media is very feasible and can be implemented into the real learning process.
\end{abstract}

Keywords: Human Anatomy and Physiology, learning media, VR

\section{PENDAHULUAN}

\section{Latar Belakang}

Dalam perkembangannya Sistem Virtual Reality (VR) merupakan perkembangan mutakhir dari multimedia. Secara khusus, VR didefinisikan sebagai suatu lingkungan yang dibangkitkan oleh komputer, bersifat tigadimensional, dan interaktif. Lingkunganlingkungan ini dapat merupakan modelmodel dunia nyata ataupun dunia khayal. Dalam penelitian ini ditemukan masalah yaitu materi yang diajarkan cukup rumit dan abstrak. Agar tidak terlalu rumit, menurut dosen pengampu mata kuliah perlu adanya media pembelajaran yang mampu memvisualisasikan materi sistem pencernaan tersebut. VR yang dikembangkan dalam pembelajaran mata kuliah anatomi dan fisiologi manusia materi sistem pencernaan dan diharapkan agar tercapainya pemahaman yang utuh. Sehingga Berdasarkan hasil penelitian yang telah ada media berbasis VR sangat mungkin untuk terus dikembangkan kearah yang lebih baik lagi.

\section{Rumusan Masalah}

Apakah media pembelajaran berbasis VR layak digunakan sebagai Media pembelajaran pada Mata Kuliah 
Anatomi dan Fisiologi pada mahasiswa semester VI Universitas Islam Jember?

\section{Tujuan Penelitian}

Untuk mengetahui media pembelajaran berbasis VR layak digunakan sebagai media pembelajaran pada Mata Kuliah Anatomi dan Fisiologi Manusia pada mahasiswa semester VI Universitas Islam Jember.

\section{METODE PENELITIAN}

Jenis penelitian yang digunakan adalah penelitian pengembangan atau Research and Development (R\&D).

Penelitian pengembangan media belajar berbasis VR mengadopsi model pengembangan Plomp seperti pada gambar berikut.

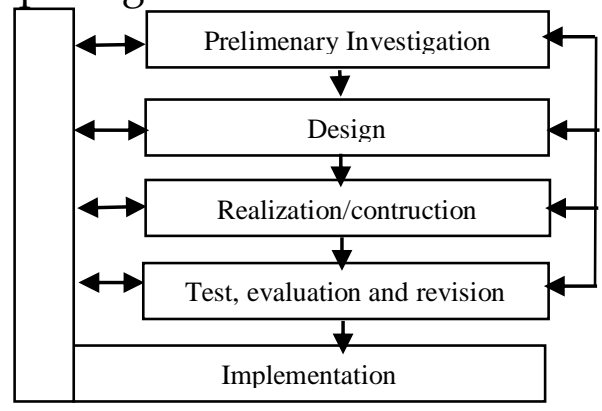

Gambar 1. Model Penelitian R \& D plom (plomp, at all, 2007)

Langkah langkah penelitian adalah 1) Fase Investigasi Awal (Preliminary Investigation) 2) Fase Desain (Design) 3) Fase Realisasi dan Konstruksi (Realization and Contruction) 4) Fase Tes, Evaluasi, dan Revisi (Test, Evaluation, and Revision) 5) Fase Implementasi (Implementation).

\section{Subjek/Objek Penelitian}

a. Tempat penelitian ini adalah mahasiswa FKIP Biologi semester VII tahun 2019 di Universitas Islam Jember.

b. Sampel yang di gunakan adalah mahasiswa semester VI untuk uji coba produk dan mahasiswa semester VI untuk implementasi produk.

\section{Metode Pengumpulan Data}

Teknik pengumpulan data adalah sebagai berikut:

1) Tahap I a. Wawancara dilakukan saat mengumpulkan informasi

b. Kuisioner digunakan pada saat validasi oleh ahli dan uji coba produk.

2) Tahap II

a. Angket / kuisioner adalah dalam tahapan Uji coba skala besar, Metode pengumpulan data dengan memberikan instrumen respon mahasiswa berupa angket/kuisioner setelah peneliti melaksanakan pembelajaran.

b. Dokumentasi, pengambilan gambar saat uji coba pemakaian.

\section{Analisis Data}

Untuk menganalisis data yang di dapatkan dari validasi ahli dan uji coba , menggunakan formulas :

$$
P=\frac{\sum x}{\sum x i} \mathrm{x} 100 \%
$$

Setelah dilakukan analisis awal dan konversi, selajutnya dilakukan interpretasi data dengan menggunakan kriteria penilaian menurut Arikunto (2010), yaitu:

$$
\begin{aligned}
& 76 \%-100 \%=\text { Sangat Layak } \\
& 56 \%-75 \%=\text { Layak } \\
& 40 \%-56 \%=\text { Kurang Layak } \\
& 0 \%-40 \%=\text { Tidak Layak }
\end{aligned}
$$

\section{Hasil dan Pembahasan}

Hasil Validasi oleh ahli materi dalam grafik berikut:

\section{Uji Validasi Materi}

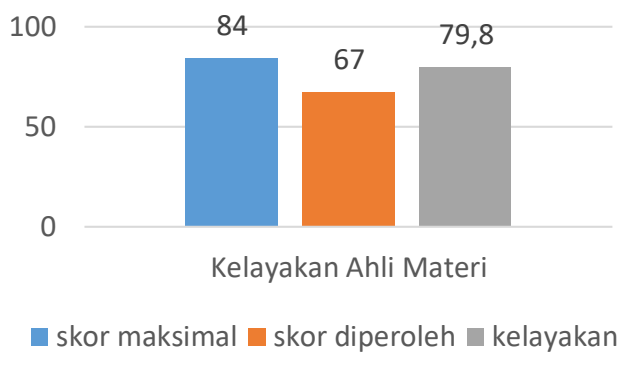


Gambar 2. Uji Validasi Materi

Validator ahli materi memperoleh skor kelayakan media sebesar 79,8\% dengan skor 67 dari 84 total skor angket yang disediakan. Berdasarkan skala oleh Arikunto bahwa materi tersebut di nyatakan sangat layak untuk di jadikan media pembelajaran VR. Peneliti tidak diberikan saran oleh validator dikarenakan materi sudah sesuai kriteria sistem pencernaan yang di kontrak kuliah.

Selaras dengan penelitian lain tentang VR yang dilakukan Penggalih Mahardika Herlambang tahun 2016 pemanfaatan VR dalam bidang kedokteran oleh mahasiswa kedokteran Universitas sebelas Maret sudah menunjukan hasil keluaran yang baik karena Didapatkan Sejumlah 100\% responden mengaku terbantu dengan smartphone Android dalam aktivitas belajar. Berdasarkan data penggunaan smartphone, teknologi VR berbasis smartphone tampaknya memiliki potensi sebagai media belajar mahasiswa kedokteran. Penelitian dengan menggunakan VR sudah terbiasa diterapkan dalam dunia pendidikan perbedaan dari peneliti satu dan lainnya hanya terdapat perbedaan yang tipis yaitu dari konten materi. Dalam prakteknya media VR selalu layak jika di jadikan media pembelajaran

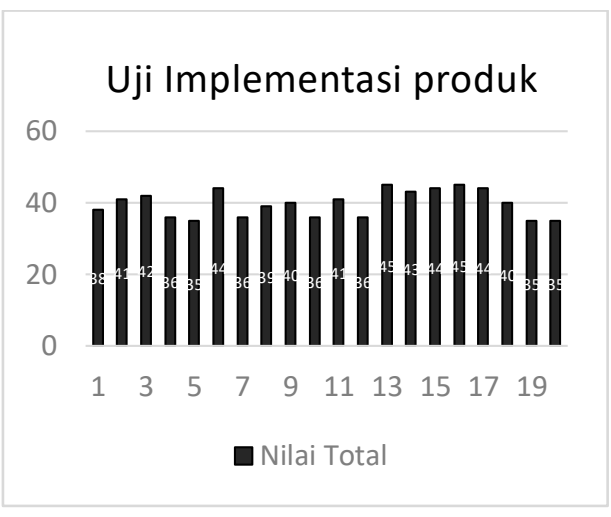

Hasil Validasi oleh ahli media dalam grafik berikut :

\section{Uji Validasi Media}

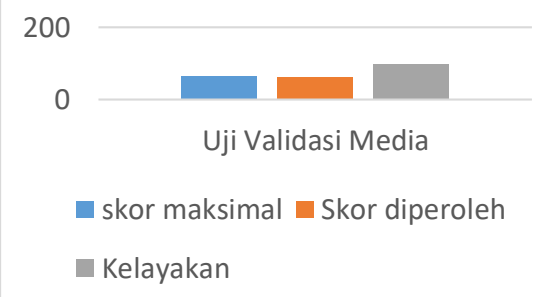

Gambar 3. Uji Validasi Media

Peneliti melakukan uji validasi dan didapatkan hasil validasi ahli media peroleh skor 96,8\% dengan skor diperoleh sebanyak 62 dari 64 total nilai skor semua item. Berdasarkan uji validitas tersebut dengan skala arikunto media VR di nyatakan sangat layak digunakan sebagai media pembelajaran.Hasil validasi tersebut merupakan dasar untuk melanjutkan ke tahap uji penerapan. Pada langkah selanjutnya peneliti melakukan pengujian langkah terakhir yaitu uji skala besar atau Implementasi produk. Produk yang telah direvisi semakin sempurna karena saran -saran yang telah direvisi.

Hasil Uji Implementasi Produk dalam grafik berikut

Gambar 4. Uji Implementasi Produk

Pada pengujian terakhir mahasiswa semester VI jumlahnya kurang lebih 24 mahasiswa, 20 mahasiswa mencoba produk VR dan memperoleh data dari mahasiswa semester 6 sebanyak 79,2\% kelayakan. Mahasiswa antusias dengan produk yang telah dikembangkan beberapa mahasiswa mempunyai ketertarikan dengan media tersebut untuk sebagai referensi penelitiannya kelak. Berdasarkan kriteria Arikunto media tersebut telah layak digunakan sebagai media pembelajaran. Dari hasil pengujian peneliti banyak mendapatkan kritik dan saran untuk merubah tampilan agar tidak membingungkan 
mahasiswa. Namun karena keterbatasan peneliti dan waktu maka peneliti memasukan kritik dan saran untuk penelitian selanjutnya. Dengan begitu media pembelajaran VR pada materi sistem pencernaan untuk semester VI dinyatakan layak digunakan.

\section{Kekurangan VR}

Media VR Ini memiliki beberapa kekurangan yang perlu dikembangkan oleh penelitian selanjutnya. Kekurangan ini berdasarkan opini penulis antara lain :

a. Media VR ini dapat menimbulkan kehilangan realitas dan juga cara berinteraksi dengan dunia nyata pada penggunanya.

b. Jika menggunakan terlalu sering atau berjam-jam menggunakannya beresiko rabun karena VR.

c. Cukup Rumit apabila orang awam yang buta bahasa pemrograman untuk membangun aplikasi ini. Karena butuh keahlian memprogram aplikasi ini.

\section{Kelebihan}

Media VR ini memiliki beberapa kelebihan diantaranya adalah:

a. Kemampuan VR bisa membuat kita bisa mendapat pengalaman visual yang realistis

b. Membuat kita berinteraksi pada berbagai obyek yang terdapat pada media yang kita saksikan menggunakan VR

\section{KESIMPULAN DAN SARAN}

Berdasarkan Penelitian yang dilakukan oleh peneliti, Media berbasis VR yang di Implementasikan di FKIP Biologi semester VI pada Mata Kuliah Anatomi dan Fisiologi
Manusia pada materi sistem pencernaan dinyatakan layak digunakan sebagai media pembelajaran dengan presentase nilai yang di dapat adalah 79,2\%

\section{DAFTAR PUSTAKA}

Andika, Dwiky. 2018. "Pengertian

Virtual Reality."https://www.it

Jurnal.com/pengertian-virtualreality.<14 Desember 2018>

Arsyad, azhar.2009.Media

pembelajaran.Jakarta:penerbit PT

Rajagrafindo Persada

Moleong, lexy J.2007.Metode

Penelitiankualitatif.Bandung:PT.Re

maja Rosdakarya.

Sugiyono,2017.Metode penelitian

kombinasi(mixed

method).Bandung:Alfabeta

Plomp, Tjeerd \& Nienke

Nieveen.2007. An Introduction to

Educational Design Research. etherland:Netherland institute for curriculum development

Riyadi ,Firman Setiawan.2011.

Aplikasi 3d Virtual Reality Sebagai Media Pengenalan Kampus Politeknik Negeri Indramayu Berbasis Mobile.Hal 1.

Yuniarti,Felintina,2011.

Pengembangan Virtual Laboratory Sebagai Media Pembelajaran Berbasis

Komputer Pada Materi Pembiakan Virus.skripsi.universitas negeri semarang 